\title{
AN APPLICATION OF MICROALLOYING AND CONTROLLED ROLLING IN SBQ* LONG PRODUCTS
}

\author{
Rafael Stella Galdino ' \\ Carolina Conter Elgert ${ }^{2}$ \\ Marcos Paulo da Silveira ${ }^{3}$ \\ Messias Prado de Almeida' \\ José Roberto Bolota ${ }^{4}$ \\ Samuel Henrique Freese '
}

\begin{abstract}
Microalloyed steels have been intensely studied as an alternative to increase strength by grain refinement and/or precipitation hardening. Long steel products have a wide range of opportunities to apply well-defined principles of controlled rolling $(C R)$ in order to increase strength and toughness with reduced costs. To evaluate the effect of microalloying elements as $\mathrm{Nb}$ and Ti with thermomechanical treatment, three conditions were tested: DIN 20MnCrS5 with hot rolling $(\mathrm{HR})$, DIN $20 \mathrm{MnCrS5}$ with $\mathrm{Nb}$ and $\mathrm{CR}$ and DIN $20 \mathrm{MnCrS5}$ with Nb+Ti and CR. Austenitic grain size, obtained by direct quenching after rolling, has shown a decrease $32 \%$ with $\mathrm{Nb}$ addition, and $29 \%$ when $\mathrm{Nb}$ and $\mathrm{Ti}$ was added. Controlled rolling generated higher grain refinement and pancacked grains near the surface. When comparing ferritic grain size, controlled rolling plus niobium and titanium additions resulted in significant reduction of $35 \%$. Yield strength increased $15 \%$ with microalloying and $\mathrm{CR}$ and more than $350 \%$ in impact toughness, even at $-40^{\circ} \mathrm{C}$.
\end{abstract}

Keywords: Controlled rolling; Niobium; Long products; Grain size.

\section{APLICAÇÃO DE AÇOS MICROLIGADOS E LAMINAÇÃO CONTROLADA EM PRODUTOS DE AÇOS LONGOS SBQ}

\section{Resumo}

Os aços microligados têm sido intensamente estudados como uma alternativa para aumento de resistência mecânica, através de refino de grão e/ou por precipitação. Produtos de aços longos possuem uma ampla gama de oportunidades de aplicação dos princípios de laminação controlada (CR) com o objetivo de aumento de resistência e tenacidade com custos competitivos. Para avaliar o efeito de microligantes como Nb e Ti com laminação controlada foram testadas 3 condições: DIN $20 \mathrm{MnCRS} 5$ com laminação a quente (HR), DIN 20MnCrS5 com adição de Nb e CR, e DIN 20MnCrS5 com adição de Nb+Ti e CR. O tamanho de grão austenítico, obtido por têmpera direta após laminação, foi reduzido em $32 \%$ com a adição de $\mathrm{Nb}$, e $29 \%$ quando considerada a adição de $\mathrm{Nb}+\mathrm{Ti}$. A laminação controlada gerou maior refino de grão e panquecamento dos grãos próximo à superfície. Quando comparado o tamanho de grão ferrítico dos aços, a laminação controlada em conjunto com a adição de nióbio e titânio resultou em uma redução de $35 \%$ desta característica. O uso de microligantes e CR aumentou em $15 \%$ o limite de escoamento e mais de $350 \%$ a tenacidade ao impacto, até mesmo a $-40^{\circ} \mathrm{C}$.

Palavras-chave: Laminação controlada; Nióbio; Produtos longos; Tamanho de grão.

\section{INTRODUCTION}

Steels in the automotive industry, in general, must achieve high strength levels without sacrificing other properties such as ductility and toughness. Among several alternatives, grain refinement is a key technique for increasing the strength and toughness of metals simultaneously $[\mathrm{I}]$.
The main goals of microalloying additions are ferrite strengthening by grain refinement, precipitation hardening and solid solution strengthening. Titanium, niobium and vanadium are very effective as microalloying elements in steel, influencing the microstructure by both a solute drag effect and the formation of nitrides and carbides [2].

\footnotetext{
'Pesquisa, Desenvolvimento \& Inovação, Gerdau, Pindamonhangaba, SP, Brasil. E-mail: rafael.stella@gerdau.com.br

${ }^{2}$ Pesquisa, Desenvolvimento \& Inovação, Gerdau, Charqueadas, RS, Brasil.

${ }^{3}$ Engenharia de Processos, Gerdau, Pindamonhangaba, SP, Brasil.

${ }^{4}$ Lean Fox Soluções em Gestão e Processos Industriais Ltda., São Paulo, SP. Brasil.

* Special Bar Quality
}

2176-1523 @ 2020. Galdino et al. Published by ABM. This is an Open Access article distributed under the terms of the Creative Commons Attribution License, which permits unrestricted use, distribution, and reproduction in any medium, provided the original work is properly cited. 
Recently, considerable work has been focused upon throughout the world studying the addition of $\mathrm{Nb}$ to long product applications assisting the steelmaker in minimizing raw materials costs in hot rolled beams, rebar and forgings [3].

For long product applications, the design of alloying and corresponding processing route is based on the specific needs, mechanical properties, machinability, cold formability, high temperature carburizing, section size and shape of each application. [4].

In general, higher carbon content is required due to hardenability of quenched and tempered steels. However, the solubility of $\mathrm{Nb}$ products decrease as carbon content increase becoming relatively low for steels with more than $0.2 \% \mathrm{C}$ and considerably low for $0.4 \% \mathrm{C}$ [3].

The rolling process of bar rolling mills are different from well-known plate and hot strip mills:

- Short reheating time in temperatures that do not usually allow for complete precipitates dissolution;

- Layouts are usually continuous, which means that interpass times are shorter than plates and hot strip mills;

- Pass design are pre-defined with relatively fixed groove design, with box, diamond, oval and round shapes.

- As dimensional tolerances should be tight, low deformation in finishing passes are common and necessary.

De Ardo [5] review article points out that small deformations promote longer times for precipitation. Because of the important influence of interpass time, solute effects would become more important, and the inhibition of recrystallization largely takes place by means of solute drag. In solid solution, microalloying elements retard all diffusion-controlled processes $[2,5,6]$.

Niobium is the most effective of the three micro-alloying elements in this context, followed by titanium. During hot rolling of steel, the solute drag effect assists in grain refinement by preventing secondary grain growth during the interpass time, since grain growth is a diffusion-controlled process $[2,5,6]$.

The aim of this work is to investigate microalloying and processing contributions in long products in order to obtain high strength and high toughness steels for engineering bars (SBQ - Special Bar Quality).

\section{MATERIAL AND METHODS}

The chemical composition, rolling schedule, mechanical properties and microstructure analysis are described below.

\section{I Chemical Compositions}

Three heats were produced in an EAF melt shop, vacuum degassed and casted by a continuous casting machine with a $155 \mathrm{~mm}$ square section, according to the compositions of a DIN $20 \mathrm{MnCrS5}$ steel showed in the Table I. As can be seen, different combinations of $\mathrm{Al}, \mathrm{Nb}$ and Ti were produced.

\subsection{Rolling Schedule}

Critical temperatures of the steels were calculated following Equations I to 6 in order to define the best parameters for rolling.

The solubilization temperature of niobium carbonitrides was calculated using Irvine's Equation I, considering the effect of titanium as effective nitrogen content in Equation 2 [7]. Non-recrystallization temperature $\left(T_{n r}\right)$, temperatures for $95 \%(\mathrm{RLT})$ and $5 \%$ (RST) of recrystallization were also calculated according to Equations 3, 4 and 5, and Ar3 obtained by Equation 6 [2,7-9].

$$
\begin{aligned}
& T_{s}=6770 /\left(2.26-\log \left([N b]\left[C+(12 / 14) N_{\text {eff }}\right)\right.\right. \\
& N_{\text {eff }}=[N]-(14 / 48)[T i] \\
& \boldsymbol{T}_{\boldsymbol{n} \boldsymbol{r}}=887+464 \mathrm{C}+6445 \mathrm{Nb}-644 \sqrt{\mathrm{Nb}}+ \\
& 732 \boldsymbol{V}-230 \sqrt{\boldsymbol{V}}+890 \mathrm{Ti}+363 \mathrm{Al}-357 \mathrm{Si} \\
& \boldsymbol{R L T}=174 \log ([\mathrm{Nb}][\boldsymbol{C}+(12 / 14) N]+1444 \\
& \boldsymbol{R S T}=\boldsymbol{R L T}-75 \\
& \mathrm{Ar}_{3}=910-310 \mathrm{C}-80 \mathrm{Mn}-20 \mathrm{Cu}-15 \mathrm{Cr}-55 \mathrm{Ni}-80 \mathrm{Mo}
\end{aligned}
$$

Billets of the 3 steels were reheated and soaked for 30 minutes, descaled and rolled in a continuous rolling mill, passing through roughing, intermediate passes, and a finishing passes schedule with a 3-roll technology equipment (Kocks block). Reductions in finishing passes are small, in order to achieve tight dimensional tolerances, as bars rolling of SBQ steels require.

Hot rolling process with the Al-steel was performed with the roughing temperature higher than RLT and

Table I. Chemical composition of DIN $20 \mathrm{MnCrS5}$

\begin{tabular}{cccccccccccc}
\hline Steel & $\mathbf{C}$ & $\mathbf{M n}$ & $\mathbf{S i}$ & $\mathbf{P}$ & $\mathbf{S}$ & $\mathbf{C r}$ & $\mathbf{N i}$ & $\mathbf{M o}$ & $\mathbf{C u}$ & $\mathbf{A l + N b + T i *}$ & $\mathbf{N}^{*}$ \\
\hline $\mathrm{Al}$ & 0.19 & $\mathrm{I} .16$ & 0.25 & 0.017 & 0.020 & 1.12 & 0.09 & 0.03 & 0.14 & $200-400$ & $<100$ \\
$\mathrm{AlNb}$ & 0.19 & $\mathrm{I} .13$ & 0.24 & 0.017 & 0.025 & 1.02 & 0.15 & 0.04 & 0.15 & $400-700$ & $>100$ \\
$\mathrm{AINbTi}$ & 0.18 & $\mathrm{I} .14$ & 0.22 & 0.015 & 0.022 & 1.04 & 0.16 & 0.04 & 0.15 & $400-1000$ & $>100$ \\
\hline
\end{tabular}

* values in ppm. 
intermediate and finishing temperatures achieved partial recrystallization region. Al-steel was not controlled rolled because of low recrystallization temperatures required and no niobium available to promote recrystallization delay. This condition was named as "Al-HR".

Controlled rolling process of $\mathrm{Nb}$ and $\mathrm{Nb}+\mathrm{Ti}$ consisted on performing roughing passes temperatures higher than RLT and intermediate and finishing temperatures among RST and $\mathrm{A}_{\mathrm{r} \cdot 3}$. Controlled rolled steels with $\mathrm{Al}-\mathrm{Nb}$ and $\mathrm{Al}-\mathrm{Nb}-\mathrm{Ti}$ additions were named as "Al-Nb-CR" and "Al-Nb-Ti-CR", respectively.

All three conditions were cooled in the same cooling rate $0,5-I, 0^{\circ} \mathrm{C} / \mathrm{s}$. Samples right after the last pass were cut for austenitic grain size evaluation. Figure I shows a schematic design of the rolling processes used in this work.

\subsection{Mechanical Properties and Microstructure Analysis}

Five samples for tensile tests and six samples for Charpy V-notched tests were cut for each steel from mid radius regions. Ultimate tensile strength (UTS), Yield Strength (YS), Reduction of Area (ROA), Elongation (El.) and Charpy tested in $20^{\circ} \mathrm{C}\left(120^{\circ} \mathrm{C}\right)$ and $-40^{\circ} \mathrm{C}\left(\mathrm{I}-40^{\circ} \mathrm{C}\right)$ were statistically evaluated by analysis of variance (ANOVA) and compared with Games-Howell test to define which of the steels have statistically different results. The level of significance used was $5 \%$, meaning that if $p$-value lower than $5 \%$, a significant difference would be found.

Microstructure of the region among $1 / 4$ and $1 / 2$ radius of the longitudinal section was evaluated with Nital $2 \%$ etching and grain size was evaluated with linear intercept method according to ASTM EI I 2 [I0].

Austenitic grain size of samples quenched after last pass during rolling were analyzed. The region among $1 / 4$ radius and $1 / 2$ radius of the longitudinal section was evaluated with $2 \%$ picric acid aqueous solution etching and grain size was measured with linear intercept method according to ASTM EII2. The same statistical methods were used to compare austenitic grain size and ferritic-perlitic grain size.

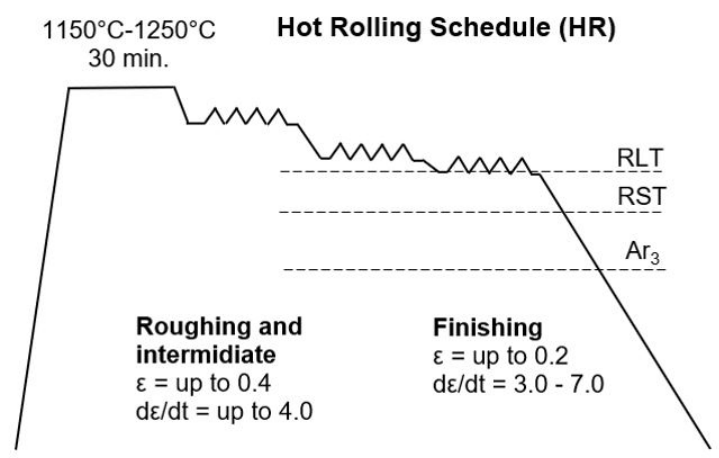

\section{RESULTS AND DISCUSSION}

\section{I Chemical Composition and Rolling Schedule}

The critical temperatures for the rolling schedule, showed in Table 2, were calculated according to Equations I to $6 . \mathrm{Nb}$ and $\mathrm{Ti}$ enables controlled rolling to be done in current rolling mill layout. As chemical compositions use the same steel base (DIN 20MnCrS5), Ar3 values were the same. For this reason, unless precipitates effects, ferrite transformation should occur in similar temperatures. The temperature of the final passes was also higher than Ar3.

Table 3 shows mean austenitic grain size for mid radius regions of the three steels. Microalloyed steels presented smaller grain sizes compared to Al-HR steel, as expected by microalloying addition and controlled rolling. Figure 2 shows austenitic grain size of mid radius regions of Al-HR (a), Al-Nb-Ti-CR (b) and Al-Nb-CR (c).

Figure 2d illustrate that controlled rolling generated pancaked grains in the surface, but with a mixing of fine equiaxed, large elongated and fine elongated grains. As a temperature prediction is not feasible yet, a hypothesis should be considered: temperature variation in the cross section of the bar, leading to partial recrystallization. Elgert et al. [1] and Rajkumar [6] advice that high reduction rates in temperatures below Tnr are necessary to take advantage of controlled rolling.

$\mathrm{Nb}$ and $\mathrm{Nb}$-Ti added steels have shown an important grain refinement compared to Al-HR. However, no

Table 2. Critical temperatures for tested alloys

\begin{tabular}{cccccc}
\hline Steel & $\mathbf{T}_{\text {sol Nb }}$ & $\mathbf{T}_{\text {nr }}$ & RST & RLT & $\mathbf{A r}_{3}$ \\
\hline Al & 984 & 872 & 846 & 921 & 734 \\
Al-Nb & 1295 & 1033 & 1009 & 1084 & 731 \\
Al-Nb-Ti & 1296 & 1067 & 1012 & 1087 & 733 \\
\hline
\end{tabular}

Table 3. Austenitic (A) grain size measurements

\begin{tabular}{cc}
\hline Steel & Austenitic grain size $(\mu \mathrm{m})$ \\
\hline Al-HR & $30.3 \pm 2.8$ \\
Al-Nb-CR & $20.6 \pm 1.4$ \\
Al-Nb-Ti-CR & $21.5 \pm 1.4$ \\
\hline
\end{tabular}

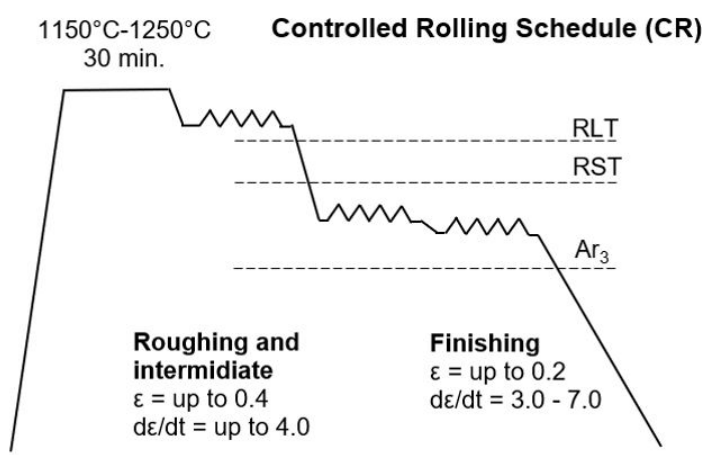

Figure I. Hot rolling schedules used during rolling. 


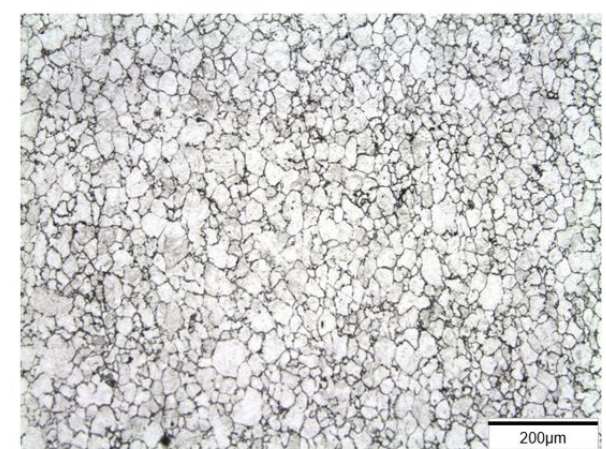

(a)

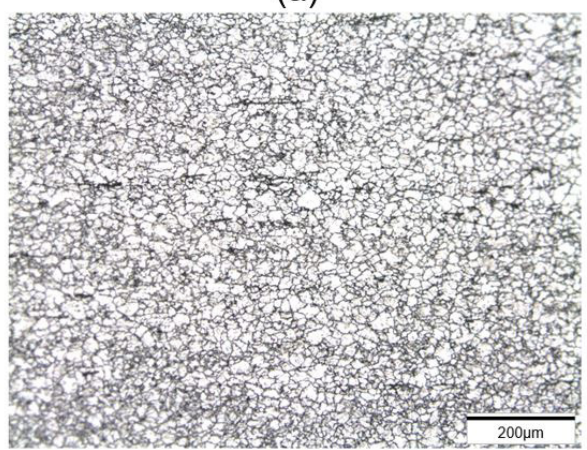

(c)

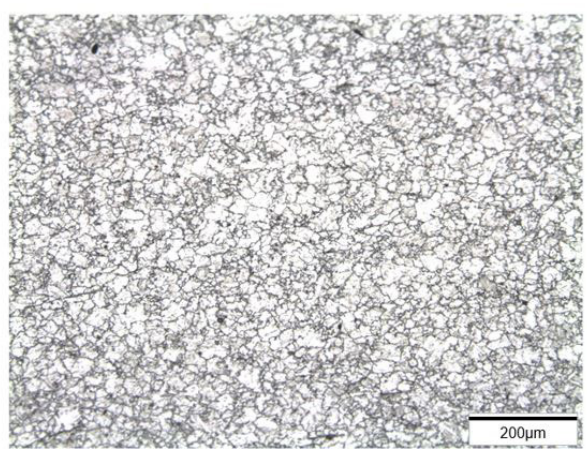

(b)

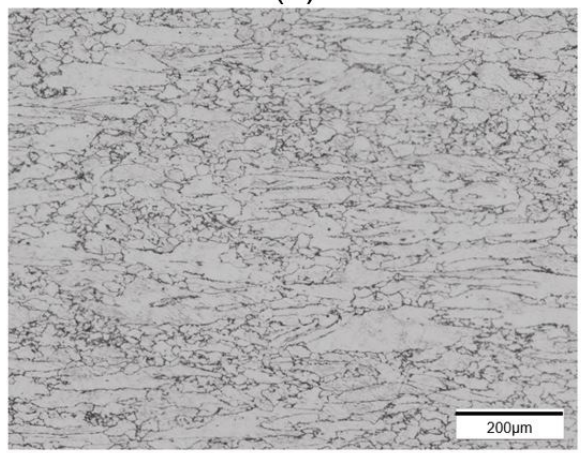

(d)

Figure 2. Austenitic grain size of longitudinal section of (a) mid-radius of Al-HR, (b) mid-radius Al-Nb-Ti-CR, (c) mid radius of Al-Nb-CR and (d) surface of Al-Nb-CR. Etched with aqueous solution of picric acid $2 \%$.

Table 4. Mechanical properties, regression coefficient and p-value of ANOVA analysis

\begin{tabular}{cccccc}
\hline Properties & Al-HR & Al+Nb-CR & Al+Nb+Ti-CR & P-value & $\mathbf{R}_{\text {ajust }}$ (\%) \\
\hline TS (MPa) & $650 \pm 2 I$ & $616 \pm 4$ & $595 \pm 8$ & 0.000 & 80.31 \\
YS (MPa) & $380 \pm 18$ & $436 \pm 7$ & $403 \pm 7$ & 0.002 & 75.86 \\
YS/UTS (\%) & $58.1 \pm 1.5$ & $70.8 \pm 1.4$ & $67.8 \pm 1.8$ & 0.000 & 92.26 \\
ROA (\%) & $67.3 \pm 2.7$ & $71.8 \pm 1.2$ & $70.4 \pm 3.3$ & 0.039 & 30.23 \\
El. (\%) & $23.3 \pm 1.2$ & $25.7 \pm 1.1$ & $26 \pm 2.4$ & 0.033 & 28.98 \\
I $20^{\circ} \mathrm{C}(\mathrm{J})$ & $47 \pm 9$ & $174 \pm 5$ & $202 \pm 29$ & 0.000 & 92.08 \\
I $-40^{\circ} \mathrm{C}(\mathrm{J})$ & $12 \pm 2$ & $130 \pm 19$ & $183 \pm 17$ & 0.000 & 95.03 \\
\hline
\end{tabular}

difference in grain size could be found among Al-Nb-CR and $\mathrm{Al}-\mathrm{Nb}-\mathrm{Ti}-\mathrm{CR}$ steels.

It is possible that the main cause for grain refinement obtained was solute drag mainly by $\mathrm{Nb}$ addition. The interpass time and total rolling time in bar rolling mills are very short and precipitation during rolling should not be extensive. The inhibition of recrystallization largely takes place by solute drag.

\subsection{Mechanical Properties}

Results of tensile tests and Charpy V-notched tests are presented in Table 4. Reduction of area (ROA) and elongation (EI.) have showed $p$-values of ANOVA analysis lower than $5 \%$, however, these properties haven't had good regression coefficients. Tensile strength (TS), Yield strength (YS), YS/TS ratio and absorbed energy in $20^{\circ} \mathrm{C}$ and $-40^{\circ} \mathrm{C}$ had significant differences and good regression coefficients.
Controlled rolling and microalloying with $\mathrm{Nb}$ increase $15 \%$ the yield strength compared to standard condition as illustrated in Figure 3a. Microalloying with $\mathrm{Nb}$ or $\mathrm{Nb}$ and $\mathrm{Ti}$ increased $\mathrm{YS} / \mathrm{TS}$ possible due to grain refinement and precipitation hardening. Tensile strength also decreased compared to Al-HR.

Significant statistical differences were found for all Charpy tests comparisons. Controlled rolling and microalloying enabled great increases in absorbed energy in $20^{\circ} \mathrm{C}$ : from 47J to 174J for $\mathrm{Nb}$ steel and 202J for $\mathrm{Nb}$ and Ti steel. For negative temperatures $\mathrm{Al}-\mathrm{HR}$ presented I2J of absorbed energy, Al-Nb-CR I30J, and Al-Nb-Ti-CR I83J. This phenomenon should be related to grain refinement and microstructure features described later in this text. It is possible to assume that ductile-brittle transition temperature was severely reduced by microalloying addition and controlled processing. 


\subsection{Microstructure Analysis}

Microstrutures of analyzed steels are presented in Figure 4. Al-HR in (a) has some acicular microstructures inside pearlite colonies highlighted by yellow arrows, and higher pearlite fraction (I2\%-17\% more than microalloyed steels) according to Table 5. Large pearlite colonies and acicular microstructures contribute to poor results of impact toughness of standard steel. Figures $4 \mathrm{~b}$ and $4 \mathrm{c}$ show more homogeneous distribution of ferrite and pearlite grains.

Ferrite fraction of Al-Nb-CR and Al-Nb-Ti-CR were almost $60 \%$ compared to $41.2 \%$ of Al-HR steel. This fact contributes for absorbed energy increase. Better results of

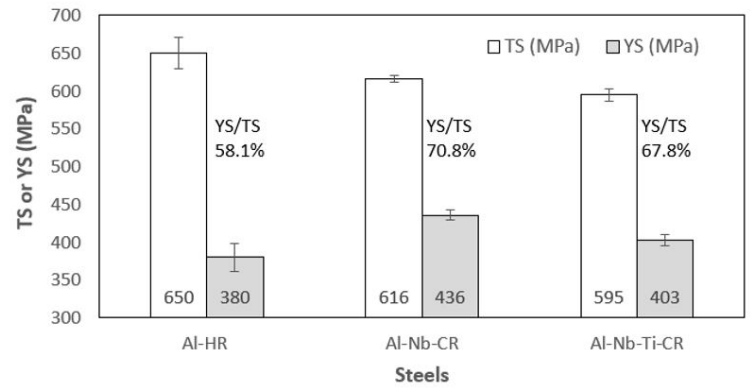

(a)
Charpy in $\mathrm{Nb}+\mathrm{Ti}$ steel in $20^{\circ} \mathrm{C}$ and $-40^{\circ} \mathrm{C}$ could be related to lower bainite content compared to $\mathrm{Nb}$ microalloyed.

Grain size of microalloyed steels are 34\% thinner than Al-HR steel, probably due to solute drag effect. The grain size evaluation was performed in mid-radius region, where samples for tensile tests and Charpy were taken.

Mixed microstructures found inside pearlite colonies are mainly granular bainite, probably associated to microinclusions. Figure 5a shows pearlite and granular bainite in Al-HR steel. Figure $5 \mathrm{~b}$ presents Al-Nb-CR steel thinner pearlite colonies, apparently with lower interlamellar distance. Although all steels were air cooled, controlled rolled steels would reach cooling bed with lower temperature, leading to lower interlamellar space in pearlite.

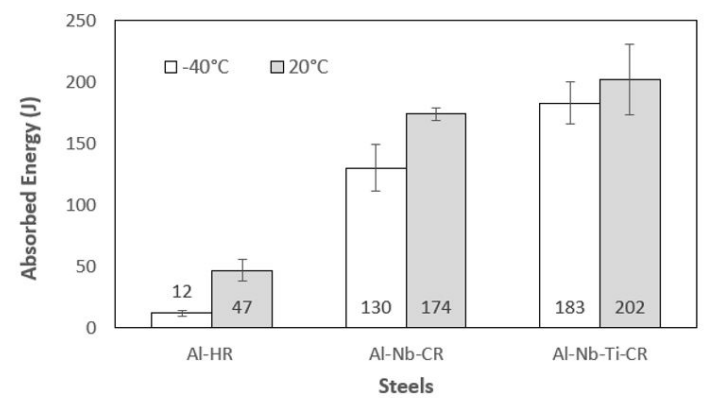

(b)

Figure 3. (a) Yield strength (YS), tensile strength (TS) and (b) absorbed energy (J).

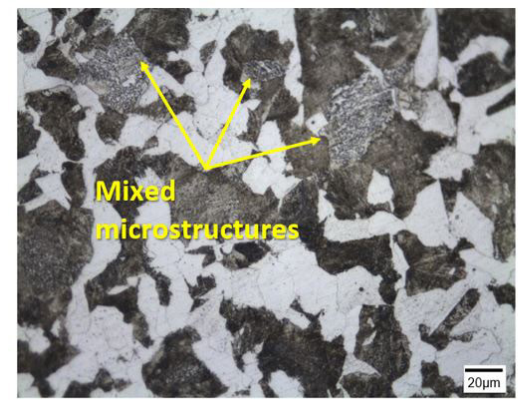

(a)

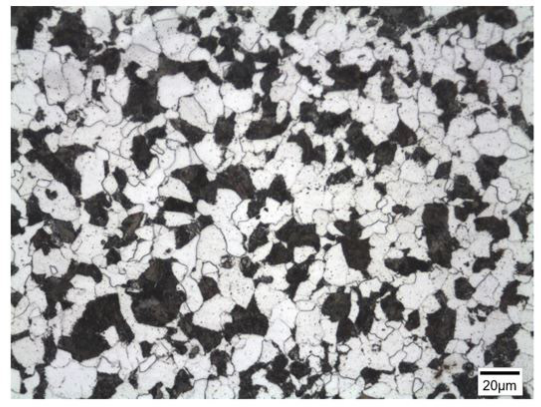

(b)

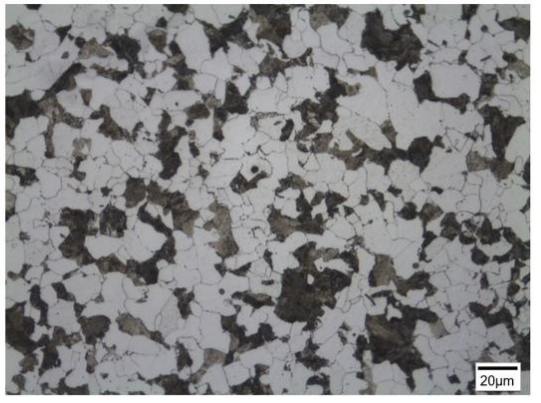

(c)

Figure 4. Microstructures of transversal section from Charpy samples tested in $-40^{\circ} \mathrm{C}$. (a) Al-HR, (b) Al-Nb-CR, (c) Al-Nb-Ti-CR. Nital $2 \%$ etched.

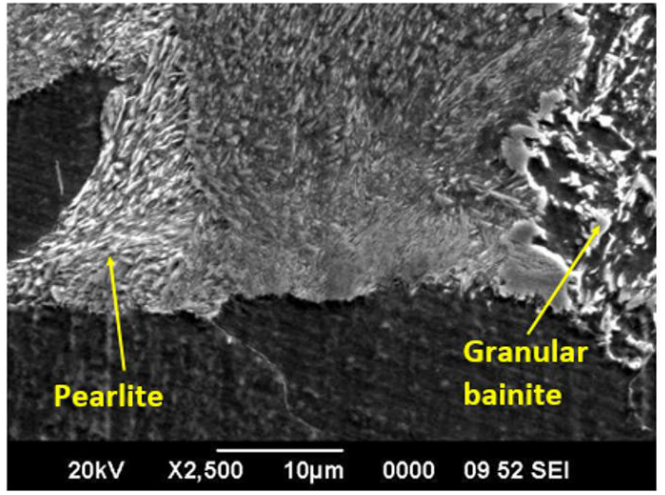

(a)

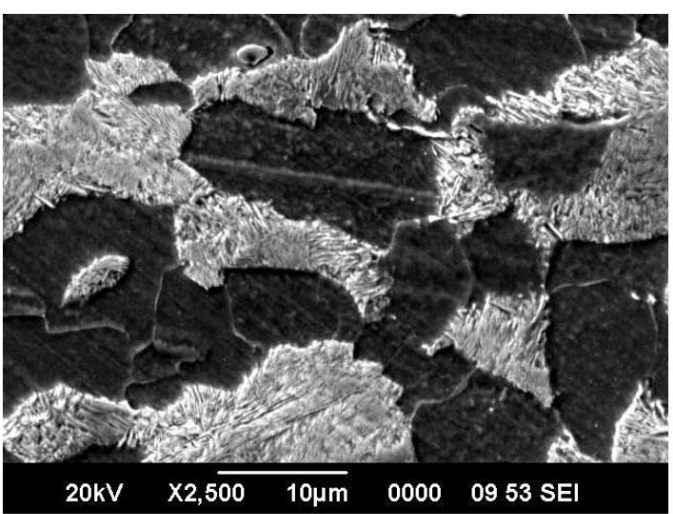

(b)

Figure 5. SEM micrographs of transversal section of (a) Al-HR and (b) Al-Nb-CR. Nital $2 \%$ etched. 
Another interesting finding in this work was the banded microstructure in microalloyed steels. Figure 6 brings micrographs of the steels in rolling direction. The notch of Charpy samples were perpendicular to the banding direction. Longitudinal section of Al-Nb-Ti-CR steels were severely banded, as can be seen in Figure 6b. The same effect could be noticed in $\mathrm{Al}-\mathrm{Nb}-\mathrm{CR}$. Al-HR was not banded in the same degree.

Several authors [ I I- I3] analyzed causes of ferrite-pearlite banding in steels. Banding mainly depends on three factors: the micro-segregation of alloying elements, the cooling rate during the transformation, and the austenite grain size. During solidification, alloying elements having partition coefficients higher than I (ex. Mn, Si, Cr, P, S, Nb and Ti) are rejected, resulting in high solute content region. The distribution of solute provides basis for microchemical banding [13]. During cooling, the ferrite starts to nucleate in the regions with a high A3 transition temperature, which causes the carbon to redistribute. The carbon is piled up in regions with a low A3 transition temperature. The increase in carbon content will lower the local A3 transition temperature even further. Eventually, the composition in these regions becomes eutectoidic and pearlite can form if the temperature is below the AI transition temperature [I I].

One important aspect that HSLA steel manufactures and the literature indicates is the homogeneity of precipitate distribution. The formation of large $(>I \mu \mathrm{m}) \mathrm{Nb}$-rich precipitates particles are generally associated to interdendritic pearlitic regions, and frequently associated to $\mathrm{MnS}$ inclusions [14].

Figure $7 \mathrm{a}$ and $\mathrm{b}$ demonstrate occurrences of $\mathrm{NbC}$ precipitated $(\sim \mathrm{l} \mu \mathrm{m})$ near $\mathrm{MnS}$ inclusions for $\mathrm{Nb}$ and $\mathrm{Nb}$ and

Table 5. Grain size and microstructure quantification

\begin{tabular}{ccccc}
\hline Steels & $\begin{array}{c}\text { Grain size } \\
(\boldsymbol{\mu} \mathbf{m})\end{array}$ & $\begin{array}{c}\text { Ferrite } \\
(\%)\end{array}$ & $\begin{array}{c}\text { Pearlite } \\
(\%)\end{array}$ & $\begin{array}{c}\text { Bainite } \\
(\%)\end{array}$ \\
\hline Al-HR & $23.3 \pm 1.3$ & $41.2 \pm 2.4$ & $39.3 \pm 3.3$ & $19.5 \pm 1.0$ \\
Al-Nb-CR & $15.3 \pm 1.1$ & $59.1 \pm 2.6$ & $22.5 \pm 1.6$ & $18.5 \pm 2.6$ \\
Al-Nb-Ti-CR & $15.0 \pm 0.6$ & $60.9 \pm 1.1$ & $27.5 \pm 2.1$ & $11.5 \pm 2.9$ \\
\hline
\end{tabular}

(a)

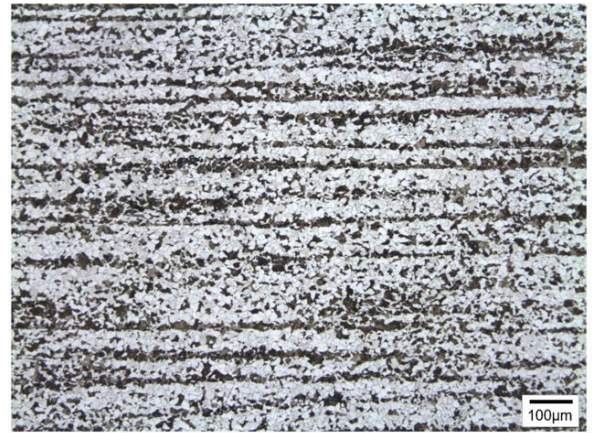

(b)

Figure 6. Microstructures of mid-radius longitudinal section of of (a) Al- HR, (b) Al-Nb-Ti-CR. Etched with Nital 2\%.

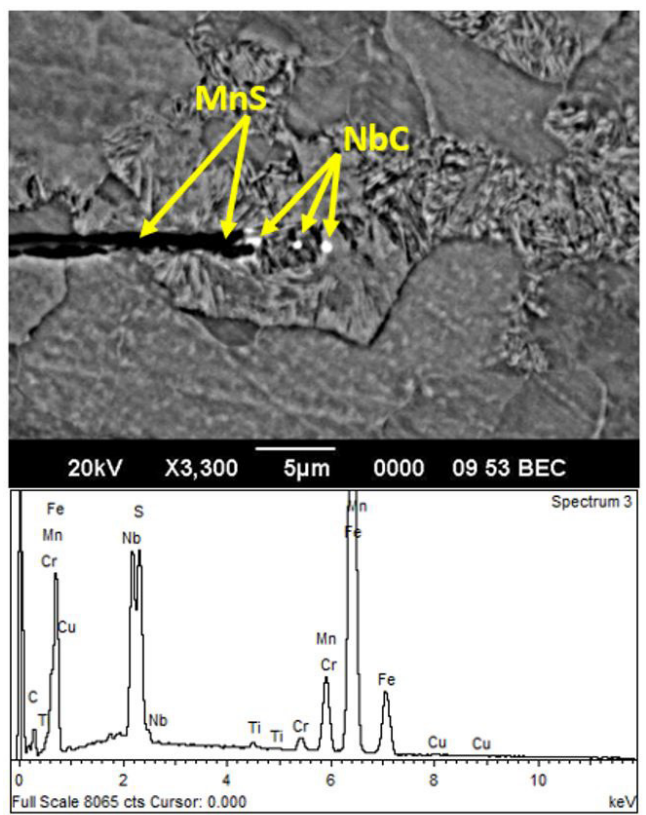

(a)

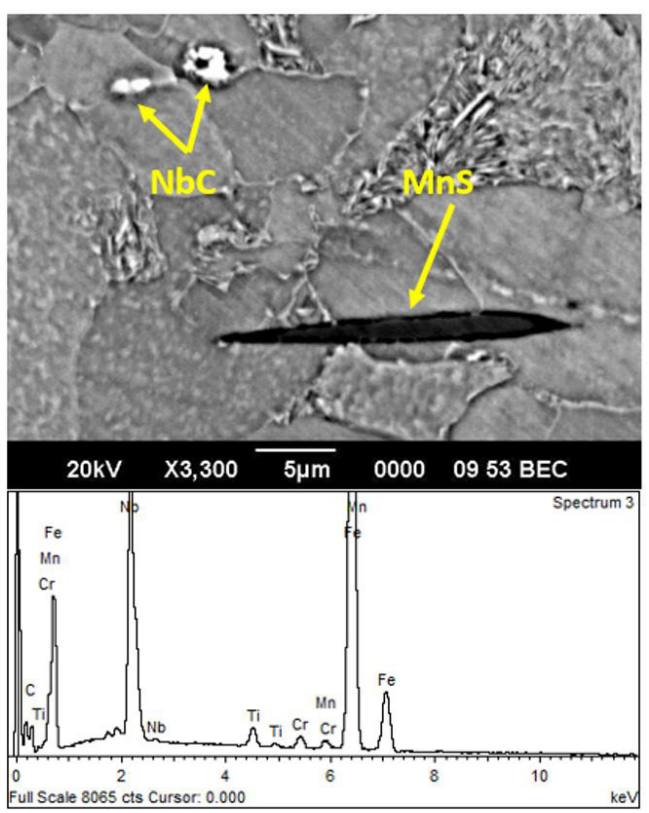

(b)

Figure 7. SEM and EDS analysis of coarse $\mathrm{NbC}$ and $\mathrm{MnS}$ precipitates. (a) Al-Nb-CR and (b) Al-Nb-Ti-CR. Nital $2 \%$ etched. 
Ti steels. For all three steels tested, sulphide inclusions were present. In long steels, after cold forming or hot/warm forging, the pieces need to be machined to obtain final shapes and tolerances. Therefore, higher sulphur content increases the challenge of long steels to achieve small and homogeneous grain sizes.

\section{CONCLUSIONS}

The main conclusions of this contribution for controlled rolling of long products are:

- It was possible to obtain significant austenitic grain refinement with $\mathrm{Nb}$ and $\mathrm{Nb}+\mathrm{Ti}$ addition. A grain size reduction from $30 \mu \mathrm{m}$ to $20 \mu \mathrm{m}$ in mid radius region was obtained. However, pancacked grains in surface were heterogeneous and have showed abnormal grain growth. Characteristics of rolling process indicate that solute drag would be the main mechanism that causes recrystallization delay and grain refinement;

- Microalloying promoted 15\% of increase in yield strength and more than $350 \%$ in absorbed energy in Charpy impact testing. Grain refinement and higher ferrite fraction should be responsible for absorbed energy increase and TS reduction of microalloyed steels compared to Al-HR;

- Controlled rolling and microalloying addition were responsible for ferrite grain refinement, but Ti have not enabled higher grain refinement as expected. Nevertheless, Al-Nb-Ti-CR achieved higher absorbed energy in $-40^{\circ} \mathrm{C}$, indicating a possible lower ductile brittle transition temperature;

- Microalloyed addition and relatively low cooling rate apparently caused ferrite-pearlite banding, due to microchemical segregation of high partition coefficient ( $\mathrm{Nb}$ and $\mathrm{Ti}$ );

- Coarse precipitates of $\mathrm{NbC}$ appeared near MnS indicating interdendritic segregation.

\section{Acknowledgements}

The authors would like to thank Gerdau, specially Rolling Mill team, Technology of Special Steel team, and CBMM for the support in resources, time, knowledge and insights, which highly contributed for this work.

\section{REFERENCES}

I Elgert CC, Teichmann L, Bastos F, Bolota JR. Development of high strength and high toughness steels. In: Anais do $36^{\circ}$ SENAFOR; 2016 Out 5-7; Porto Alegre; Brazil. Porto Alegre: UFRGS.

2 Vervynckt S, Verbeken K, Lopez B, Jonas JJ. Modern HSLA steels and role of non-recrystallisation temperature. International Materials Reviews. 2012;57(4): I87-207.

3 Klinkenberg C, Jansto SG. Niobium microalloyed steel for long products. In: Proceedings of the International Conference on New Developments in Long and Forged Products: Metallurgy and Applications; 2006; Winter Park, Colorado. USA: AIST; 2006. p. 135-I4I.

4 Chui Z. Thermomechanical processing of structural steels with dilute niobium additions [thesis]. Sheffield: University of Sheffield; 2016.

5 De Ardo AJ. Niobium in modern steels. International Materials Reviews. 2003;48(6):37I-402.

6 Rajkumar C. Increasing the yield strength of niobium nicroalloyed reinforcing bar [thesis]. Johannesburg: University of Witwatersrand; 2008.

7 Gorni AA. Steel Forming and Heat Treating Handbook. [cited 2019 June 5]. Available at: http://www.gorni.eng.br/e/ Gorni_SFHTHandbook.pdf.

8 Gorni AA. Cálculo da temperatura de não recristalização para aços microligados, em função da interação entre a precipitação, e recristalização da austenita. Revista Escola de Minas. 1999 [cited 2019 June 5];52(I):2I -25. Available at: http://www.gorni.eng.br/Gorni_REM_Jan 1999.pdf

9 Ouchi C, Sampei T, Kozasu I. The effect of hot rolling condition and chemical composition on the onset temperature of $Y$ - $\alpha$ Transformation after Hot Rolling. Transactions ISIJ. 1982;22:2 I 4-222.

10 American Society for Testing and Materials. ASTM E I I2: Standard Test Method for Determining Avarage Grain Size. West Conshohocken: ASTM International; 2013.

I I Offerman SE, Van Dijk NH, Rekveldt MT, Sietsma J, Van der Zwaag S. Ferrite/pearlite band formation in hot rolled medium carbon steel. Materials Science and Technology. 2002; 18:297-303.

I 2 Hashimoto S, Nakamura M. Effects of microalloying elements on mechanical properties of reinforcing bars. ISIJ International. 2006;46(I0):I510-I5I5. 
13 Thompson SW, Howell PR. Factors influencing ferrite/pearlite banding and origin of large pearlite nodules in a hypoeutectoid plate steel. Materials Science and Technology. 1992;8:777-784.

14 Roy S, Patra S, Neogy S, Laik A, Choudary SK, Chakrabarti D. Prediction of inhomogeneous distribution of microalloy precipitates in continuous-cast high-strength, low-alloy steel slab. Metallurgical and Materials Transactions A. $2012 ; 43: 1845-186$

Received: 30 Nov. 2019

Accepted: 18 May 2020 